KAWISTARA

\title{
MEMAHAMI EKSISTENSI MANUSIA MELALUI MEDIA KOMUNIKASI
}

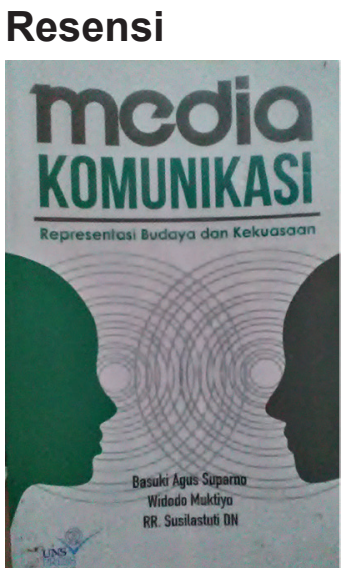

sebuah simbol yang bernama komunikasi dalam berinteraksi bersama dengan sesamanya atau makhluk hidup lainnya. Menciptakan, menggunakan, lalu menyalahgunakannya, itulah hakikatnya fase kehidupan manusia di muka bumi yang lekat dengan kehidupan sosial sehari-hari. Adanya sebuah sistem simbol dan kebahasaan yang diciptakan ini menuntut masyarakat dunia untuk memahami betapa pentingnya arti membaca, transformasi pengetahuan, dan menumbuhkan pengertian yang lebih luas dan membuat segala hal yang awalnya berada di luar jangkauan menjadi lebih dinamis. Seperti contohnya yang sudah banyak ditemukan dalam kehidupan masa kini, keberadaan internet, telepon seluler, radio, dan televisi adalah bukti bahwa segala interaksi simbol dan kebahasaan itu sudah tidak terbatas oleh jarak dan waktu.

Kemajuan zaman dewasa ini dengan berbagai macam penemuan di bidang teknologi yang mendorong dinamisnya media komunikasi antarsesama manusia di seluruh penjuru dunia berimplikasi banyak atau dengan kata lain memiliki multiplier effect. Misalnya dalam segi sosial, ekonomi, budaya, dan politik. Kondisi inilah yang menjadi pendorong penulis untuk membuat buku berjudul "Media Komunikasi Representasi Budaya dan Kekuasaan" demi mendorong tumbuhnya pemahaman mengenai karakter media komunikasi, potensi, dan segala kekuatan yang ada di dalamnya. Dalam lingkungan masyarakat, media terkadang dipakai sebagai alat untuk mempengaruhi kepercayaan tertentu yang sudah dianut oleh manusia, meyakinkan ideologi, mencitrakan nama, menyuarakan kebenaran, dan yang paling parah adalah menyebarkan berita bohong atau yang lazim kita kenal dengan istilah hoax. Di sisi lainnya, dalam perkembangan kehidupan hingga saat ini, media komunikasi telah hadir dengan sebuah perubahan bentuk komunikasi yang tidak pernah dibayangkan sebelumnya. Keberadaan cara berkomunikasi virtual melalui media sosial adalah sebuah terobosan signifikan untuk mendobrak jarak dan waktu yang pada zaman dahulu tidak pernah dapat dilakukan, tetapi sekarang menjadi sebuah keniscayaan yang tidak terhindarkan.

Perkembangan yang terjadi dalam teknologi komunikasi dan informasi tidak bisa serta merta dilepaskan dari dimensi budaya yang ada dalam suatu negara. Adanya kemajuan cara komunikasi semacam ini menimbulkan masifnya pertukaran lintas budaya antara 
satu negara dengan negara lainnya di seluruh dunia yang terjadi akibat praktik-praktik media. Tanpa kita sadari, besarnya perubahan perilaku mahasiswa dalam menyelesaikan tugas kuliah yang berorientasi pada internet sebagai sumber referensi membuat mereka seakan-akan semakin tidak selektif dalam memilih sumber yang lebih baik dan tepat untuk ditempatkan dalam tugasnya. Para wanita karir yang rela mengeluarkan banyak uang untuk mempercantik diri dengan berbagai merek fashion dan make up ternama hasil dari suksesnya pengaruh majalah kecantikan juga merupakan bentuk lain kentalnya representasi budaya dalam media komunikasi.

Akan tetapi, seperti yang sudah saya tuliskan di atas bahwa peran media komunikasi tidak hanya berimplikasi pada bidang budaya saja, tetapi juga telah dikupas secara mendalam dalam buku ini terkait dampaknya pada bidang lainnya, yakni konsep dan pemikiran tentang media massa, media baru, media ekonomi, media budaya, dan media politik. Melihat kedalaman materi yang disampaikan oleh penulis, saya menilai bahwa terbitnya buku "Media Komunikasi Representasi Budaya dan Kekuasaan" ini sekaligus menyiratkan pemahaman kepada pembaca tentang media komunikasi dari segi yang lebih luas. Yakni sebagai representasi budaya dan kekuasaan umat manusia. Media merupakan alat interaksi sosial yang telah mampu mengukuhkan eksistensi umat manusia di muka bumi ini. Itulah kesimpulan yang bisa pembaca dapatkan dalam buku ini. Dikatakan demikian karena pada realitasnya, keberadaan media komunikasi dalam berbagai bentuk, baik itu media massa maupun media sosial telah dimanfaatkan oleh manusia untuk jalan keluar mengatasi berbagai masalah yang terjadi dalam kehidupan sosialnya. Pada hakikatnya, manusia juga merupakan makhluk social. Untuk itu, sebagai pencipta media, seharusnya semua secara sadar maupun tidak sadar telah memanfaatkannya demi berbagai macam kepentingan, seperti sosial, ekonomi, budaya, dan politik. Dalam konstelasi politik misalnya, sering ditemukan sejumlah tokoh politik yang demi meraih kekuasaan atau suara rakyat kemudian harus bersusah payah untuk mencitrakan dirinya sedemikian rupa di muka media semata-mata hanya untuk meraih simpati publik agar memilihnya di sebuah kompetisi klasik yang bernama pemilihan umum. Selain itu, dalam penyelenggaraan pemerintahan, semua tidak pernah tahu apa yang sebenarnya sedang terjadi pada negara ini. Bahkan dalam kondisi perekonomian maupun keamanan yang sedang genting sekalipun, pemerintah berusaha menyampaikan pernyataan di depan media bahwa negara sedang dalam keadaan baik-baik saja agar tidak terjadi kepanikan luar biasa di masyarakat. Ini adalah beberapa bukti bahwa media sebagai tempat disajikannya aktualisasi diri manusia.

Meskipun demikian harus di akui juga bahwa media telah memberikan manfaat yang tidak terhingga bagi manusia itu sendiri. Satu-satunya cara kita mengetahui informasi atau berita terkini yang sedang terjadi adalah dengan berinteraksi melalui media, baik itu media massa maupun media sosial. Selain itu, ketiadaan batasan antara jarak dan waktu untuk berinteraksi dengan sesama manusia lainnya di seluruh penjuru dunia juga bisa terjadi karena keberadaan media. Akan tetapi, perlu diingat bahwa tetap ada sisi-sisi negatif yang tidak dapat dihindarkan dari adanya media. Akhirakhir ini masyarakat Indonesia sering dibuat panik bahkan hingga terjadi konflik saudara karena adanya penyebaran berita bohong terkait suatu topik tertentu yang dilakukan oleh orang-orang yang tidak bertanggung jawab. Berkembangnya budaya kebebasan berekspresi dan mudahnya seseorang untuk memiliki akun di media sosial kemudian menuliskan sesuatu hal membuat semakin rentannya penyebaran berita hoax yang menggunakan media sebagai piranti utama. Untuk itu, seiring dengan perkembangan zaman yang semakin tidak terbendung maka manusia juga dituntut untuk lebih bijak dalam memanfaatkan keberadaan media. Peran pemerintah sebagai regulator memang sangat dibutuhkan untuk menciptakan sebuah peraturan hukum yang mampu menjadi tameng pemberitaan hoax di lingkungan masyarakat. Pada akhirnya semua itu akan tetap sia-sia jika tidak mampu secara 
bijak mengkontrol diri sendiri untuk memilih menggunakan media sebagai alat kebaikankebaikan sosial, atau justru memperalat media demi melakukan tindak pidana yang merugikan orang lain.

Sama seperti halnya media komunikasi, saya menilai bahwa buku ini juga merupakan sebuah media tersendiri yang sangat cocok menjadi referensi bagi mahasiswa, akademisi atau masyarakat umum lainnya agar mampu menjadi media pembelajaran dan upaya kontrol bagi lingkungan sosial terhadap dinamika media komunikasi yang semakin maju dari waktu ke waktu. Mengingat kedalaman materi yang dikupas oleh penulis mengenai definisi dan perkembangan media komunikasi secara lebih luas yaitu sebagai representasi budaya dan kekuasaan, maka tidak salah jika saya merekomendasikan buku ini dibaca oleh masyarakat luas agar intisari yang didapatkan dari buku tersebut dapat diimplementasikan dengan baik dalam kehidupan seharihari sekaligus untuk menghindari konflik berkepanjangan yang akhir-akhir ini sering terjadi akibat salah kaprahnya masyarakat umum memanfaatkan media komunikasi yang tersedia. 